INTERNATIONAL BULLETIN OF BACTERIOLOGICAL NOMENCLATURE AND TAXONOMY

Volume 12, No. 1 January 15,1962 pp. 11-14

\begin{abstract}
INTERNA TIONAL SUB COMMIT TEE ON PHAGE TYPING OF STAPHYLOCOCCI
\end{abstract}

Report 1958-1961

To the Secretaries of the International Committee on

Bacteriological Nomenclature:

1. Membership of the Subcommittee. It was agreed at the Stockholm meeting that the Subcommittee should ordinarily include one member from each country in which phage typing is carried out. Since 1958, the number of countries with active phage typing centres has increased considerably. A list of the members of the Subcommittee as at August 1961 is appended to this report.

Although Dr. R. E. O. Williams has now left the Staphylococcus Reference Laboratory at Colindale, that laboratory, under its Director, Dr. M. T. Parker, continues to act as the International Reference Centre.

2. Comparative test of phage-typing. A set of 24 strains of staphylococci were circulated from Colindale in 1959 to all national staphylococcus laboratories and a report on the results were sent to all participants in March 1960. It showed an encouraging degree of uniformity in the results obtained for most strains, but revealed a number of discrepancies which were investigated.

In several countries, and particularly in the United States and the United Kingdom the same set of test strains were circulated to individual typing laboratories, and proved useful in checking the reproducibility of the typing techniques within the country.

A further set of test strains is being circulated in the autumn of 1961.

3. Report on phage typing methods. In view of the increasing interest in the commercial production of typing phages, it was thought useful to prepare an authoritative statement on acceptable methods for the propagation, testing and use of typing phages. Dr. Blair and Dr. Williams prepared a draft report, which was seen by members of the Subcommittee, several of whom made valuable contributions. The report has been published in Bulletin of the World Health Organization $(1961,24: 771)$; it emphasizes the importance of rigid control of phages prepared for bulk distribution. 
Page 12

INTERNATIONAL BULLETIN

4. Recommended typing phages. Included in the report mentioned above is a list. of the basic set of typing phages recommended for general use. This list, which supersedes that published in the Minutes of the Stockholm meeting is as follows:

$\begin{array}{ll}29,52,52 \mathrm{~A}, 79,80 & \text { (Group I) } \\ 3 \mathrm{~A}, 3 \mathrm{~B}, 3 \mathrm{C}, 55,71 & \text { (Group II) } \\ \text { 6, 7, 42E, 47,53,54, 75, 77 } & \text { (Group III) } \\ \text { 42D } & \text { (Group IV) } \\ 187,81 & \text { (Miscellaneous Group) }\end{array}$

Phage VA4, originally isolated by Dr. Blair, was given the number 83 , but subsequent investigation has revealed the existence of a variant of this phage and the numbering of these phages is has been reconsidered. It is proposed by Dr. Williams and Dr. Blair that the original phage be designated as $83 \mathrm{~A}$ and the variant as $83 \mathrm{~B}$.

5. Standard lytic spectra of typing phages. The lytic spectra used to characterize the typing phages are based on accumulated experience and a number of adjustments have been made. Mrs. E. A. Asheshov, working at Colindale, has prepared an exhaustive analysis of the variations in the lytic spectra regarded as typical during the last 10 years. A revised set of test strains is defined in the published report.

6. Liaison with World Health Organization. Dr. Williams has had a number of discussions with members of the staff of WHO about possible liaison of the Subcommittee with the organization. It is hoped that this can be further discussed at the Committee's meeting in Montreal.

7. Distribution of phages. It was agreed by correspon-: dence that renewal of the standard typing phages every 3 years should be sufficient. A complete new set of phages is being distributed to all national laboratories during 1961.

8. Next meeting. The next meeting of the Subcommittee will be held in Montreal on August 16 th 1962 .

J.E. Blair,

Chairman.

R. E.O. Williams

Secretary. 
BACTERIOLOGICAL NOMENCLATURE

AND TAXONOMY

\section{List of Members}

Chairman

Secretary

Australia

Bulgaria

Canada

Chile

Czechoslovakia

Denmark

Finland

France

Germany F.R.
Dr. J.E. Blair, Hospital for Joint Diseases, Madison. Avenue, One Hundred and Twenty Third Street, New York 35, N.Y., U.S.A.

Professor R. E. O. Williams, WrightFleming Institute of Microbiology, St. Mary's Hospital Medical School, Paddington, London, W. 2.

Dr. Phyllis M. Rountree, Royal Prince Alfred Hospital, Camperdown, N.S.W. Dr. M. Grigorova, Research Institute of Epidemiology and Microbiology, Blv. VI. Zaimov, 26, Sofia.

Dr. E. T. Bynoe, Department of National Health and Welfare, Laboratory of $\mathrm{Hy}-$ giene, Ottawa.

Dr. M. Rodriguez Leiva, Department of Bacteriology and Immunology, Universidad Catolica de Chile, Santiago.

Professor K. Raska, Institute of Epidemiology and Microbiology, Srobarova 48, Prague 10.

Dr. K. Rosendal, State Serum Institute, Amager Boulevard 80, Copenhagen.

Dr. I. Rantasalo, State Serum Institute, Mannerheimintie 166, Helsinki.

Dr. R. Wahl, Service des.Streptocoques, Institut Pasteur, 25 Rue du Docteur Roux, Paris $\mathrm{XV}^{\mathrm{e}}$.

Prof. Dr. H. Brandis, Hygiene-Institut der Universitat, Kreuzbergring 57, (20b) Göttingen.

D. D. R. Dr. H. Rische, Bezirks-Hygiene-Institut, Burgstrasse 37, Wernigerode.

Hungary

Dr. H. Milch, Staatl, f. Hygiene, Gyáli et 2, Budape st IX.

Israel

Dr. D. Sompolinsky, "Assaf Harofe" Hospital, Sarafand, Tel-aviv.

Italy
Professor V. Ortali, Instituto Superiore di Sanita, Rome. 
Page 14

INTERNATIONAL BULLETIN

Japan

Professor K. Ishihara, University of Gunma College of Medicine, Maebashi.

Mexico

Dr. L. E. Sanchez-Torres, Department of Microbiology, Instituto Politecnico Nacional, Escuela Nacional de Ciencias Biologicas, Apartado Postal No. 19186, Mexico, D.F.

Netherlands Dr. R. Th. Scholtens, Rijks Instituut voor de Volkagezondheid, Sterrenbos 1, Utrecht, Holland.

New Zealand Dr. J.D. Manning, National Health Institute, 52 Riddiford Street, Wellington, S.I.

Norway

Poland

Portugal

Roumania Professor Th. M. Vogelsang, Gade's Institute, Bergen.

Professor R. Pakula, State Institute of $\mathrm{Hy}-$ giene, ul. Chocimska 24, Warsaw.

Dr. M. Moreira-Jacob, National Laboratory of Veterinary Research, 701 Benfica, Lisbon 4.

Dr. M. Popovici, Institut "Dr. I. Cantacuzino", Spl. Independentei nr. 103 Raionul V.I. Lenin, Bucuresti 35 .

South Africa Dr. A. Kipps, Virus Research Unit, Medical School Observatory, Cape Town.

Sweden Dr. G. Wallmark, State Bacteriological Laboratory, Box 765, Stockholm 1.

Switzerland Dr. H. Reber, Medizinische Universitatsklinik, Burgerspital, Basel.

Turkey Dr. E.T. Cetin, Institute of Microbiology and Contagious Diseases, Faculty of Medicine, Istanbul University.

U.S.A.

Dr. Elaine L. Updyke, Staphylococcus and Streptococcus Unit, Microbiology Section, Communicable Disease Center, Bldg. 1 Room L-161, Atlanta 22, Georgia.

Yugoslavia Dr. R. Skalova, School of Public Health, "Andrija Stampar" University of Zagreb, Mirogojska Cesta 4, Zagreb.

There are also laboratories engaged in phage typing of staphylococci in Argentina, India, Korea and the U.S.S.R. but their representation on the Committee has not yet been finally determined. 